\title{
Transformation concept "Information technologies" in modern scientific discourse
}

\author{
Olexandra Rubanets \\ National Technical University of Ukraine "Igor Sikorsky Kyiv Polytechnic Institute" \\ Peremogy Avenue, 37, Kyiv-56, Ukraine, 03056, \\ rubanets@gmail.com, orcid.org/0000-0003-0363-4116
}

Received 27.04.2019, accepted after revision 10.06.2019

https://doi.org/10.31493/tit1921.0301

\begin{abstract}
The purpose of the study is to reveal the objective transformations that have occurred in information technology. Conceptualization of these transformations is also important. System, information, network and cognitive approaches allow to reveal the main aspects of the development of information technologies - technical and technological, software and hardware, network, communication, cognitive. The article considers the evolution of information technology. The relationship of information technology with its increasing role and importance of information in the life of man and society is analyzed. Information technologies are disclosed as technologies to create, store, record and process information. Technical and technological direction of information technology development is analyzed. The connection of the information technology concept transformation and development of the information society theory, in particular, the theory of post-industrial society, information society, network society, knowledge society and the digital world is revealed. The connection of the information technology concept transformation and the emergence of the media civilization and global information space is also revealed.

The article shows that the development of information technology is an important factor in the development of the information society. Technology transition (the electronic computer as a machine) to the modern stage of development of digital technologies is characterized by the formation of a single technical and technological basis for the formation of the information society.

The classification of information technology according to its application scope is proposed. Information and communication technologies
\end{abstract}

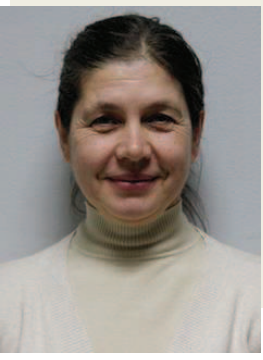

Olexandra Rubanets

Professor of the Philosophy Department

Dr. Sc. of Philosophy, Prof.

characterize subject-to-subject interactions, among which pedagogical and political technologies are primarily distinguished. Information space is separate area of information technology application. Information processing technologies in the information space are the basis of modern democratic discourse. An important area of information technology is the information sphere. Information sphere is the sphere of information activity, information exchange and information relations, the regulator of which is the information law. Information security technologies ensure the protection of human rights, society and the state in obtaining objective information. Cybersecurity technologies protect critical infrastructure. The technologies of reality - virtual, cognitive, and augmented - provide the ability of a person's consciousness and thinking to process and create new information.

Identifying the social significance of the technical and technological development of information technologies becomes the basis of recommendations for the implementation of a strategies for the formation of the information society in Ukraine.

Keywords: information technologies, information and communication technologies, network technologies, digital technologies. 
The study of the information technology concept transformation is urgent due to the growing role of information processing for public institutions and the state. Despite the fact that information technology is widely spread as a term, there are no studies on the evolution of the content of its concept. Identification of the information technology genesis characterizes modern scientific and technological progress. Changes in information technology produce significant changes in the development of man and society. The development of the theories of the information society cannot be considered as a complete reflection of the changes occurring in the information technology itself, as well as the changes that are caused by the emergence of new information technologies. That is why the development of information technology is a separate object that has self-sufficient significance.

The purpose of the study is to reveal the objective transformations that have occurred in information technology. Conceptualization of these transformations is also important. Achieving the goal involves the implementation of the following tasks:

- identify the main stages of information technology development;

- study the diversity of information technology;

- find out the impact of the main theories and concepts of the information society on the formation of conceptual differences in the definition of information technology.

The novelty of the research lies in the study of the information technology concept with its initial manifestations and the disclosure of computer technology to the conceptualization of modern network technologies, cybersecurity, and digital technologies.

The concept of information is an important prerequisite for the emergence of the concept of information technology. Today, a retrospective view of information revolutions as the development of information technologies, beginning with the advent of writing [8], is based on the fact that information exists and has been used for a very long time. However, the conceptualization of the concept of information occurs in the context of the historical back- ground of electronic computing equipment emergence. According to K.Shannon, the concept of information is characterized by "overcoming uncertainty" $[13, \mathrm{p} .162]$ in the process of choosing and making decisions in the case of some priori knowledge. K. Shannon introduces an idealization that characterizes an equal probability to choose between two possible options. Information functions as a special non-material resource that decisionmaking efficiency depends on.

A.Turing introduces a combinatorial approach and the calculation of combinations $[11, p .320]$. Turing machine was created as a combination of mechanisms. But for the first time the connection of mechanisms was intended for information processing. All previous machines turned various forms of energy into mechanical motion. The theory of mechanisms and machines arises as a consequence of the theorization of transformations that occur in mechanical systems. A.Turing creates a mathematical model of data processing [30]. The mechanical design of Turing machine becomes the embodiment of a combinatorial computational approach. The most sophisticated combinations that it creates become the embodiment of pure information.

First, the concept of "electronic computer" arises. The electronic computer considered to be a machine. And only today it is becoming increasingly clear that information technologies are opening up new worlds - virtual reality, the information sphere, the information space and cyberspace. Arpanet was the first to interlink computers. Network technologies appear as communication, messaging and communication development technologies.

The origin of communication is associated with the advent of TV-technologies. Television appears as a global data transmission system. M.McLuhan [16] considers the television to be some probe that covers the whole earth. The media civilization is born. The concept of hyper reality contributes to the birth of a media civilization as well. The emergence of hyper reality $[3$, p.80; 9, p.34] characterizes the doubling of society: alongside with real social processes, the world of simulacra emerges, which substitute real objects, events and inter- 
actions between them. Simulacra's are capable of causing feelings. Hyper reality is transformed into a special arena, where the real world appears in a special, sometimes bizarre and illusory form.

The emergence of post-industrialism contributes to the emergence of the theory of the information society. The information society acts as a society where preference is given to the service sector and knowledge production [1, p. 198]. Industrial technologies are being replaced by intelligent technologies. The concept of intellectual technology is introduced by D. Bell [2, pp. X-XI, XIV, XV-XVII]. Intellectual technology combines both scientific activity (mathematical modeling) and computer's operation. This is a combination of scientific knowledge, scientific methods and electronic computing equipment.

The study of the framework of the information society is trying to overcome technological determinism - the idea that machinery as a technology generates a new type of society. The Information Society acts as a society of the Third Wave (A. Toffler) [29] and electronic-digital society (D. Tapscott) [28, p.33-34]. This is the society in which the processing of symbolic information, rather than the processing of the substance of nature, comes first. This brings to the fore a special type of labor the processing of signs and symbols (A. Toffler) [29]. Later post-industrialism gives preference to intangible factors of the development.

The concept of information technology are associated with the theory of information society (Y. Hayashi, Y. Masuda) [15]. The study of information technology evolution enables to reveal the transition from abstract consideration of information technology as technology of processing, fixing and storing information to the disclosure of specific information technologies in various spheres of social activity. The development of information technology contributes to the introduction of the concept of the information society. The information society appears as an e-society, which doubles the information and transforms it into an electronic version (A. Shevchuk, A. Golobutsky) [26, p.93]. However, the information society appears as a society that relies on information processing. At the same time, the different nature of information - media and information related to the development of computer technology - is not taken into account. This makes it possible for a long time ignore the importance of the technical and technological direction of development of information technology.

Since the early nineties of the twentieth century, internet technologies have begun to actively develop. Information technologies are starting to be revealed not only as communication technologies. Increasingly, they are emerging as technologies of cyberspace and information system development. Virtual space technologies are arising. The institutionalization of the social manifestations of the virtual space technologies is coming around. Virtual universities, e-business, e-banking, ecommerce are appearing. Sophisticated software and hardware systems are being created, databases and knowledge bases are emerging. Information technology is increasingly associated with the development of computer engineering, design and programming. The Okinawan Charter emphasizes the importance of bridging the digital divide [18, p.53-54]. The emergence of various models of the information society indicates the various forms and rates of development of countries to a higher state of technical and technological development.

The emergence of the theory of the network society (M. Castells, P. Drucker) contributes to the removal to the forefront of network technologies. Network technologies appear as communication technologies. In American research communication acts as a message transmission. There are various models of communication. The theory of network society, network technology covers all types of communications. A network of communication is appearing. The disclosure of network technology as information reveals the social significance of information technology [7, p.83-84]. Informationalism (M. Castells) [6, p.13] is a concept that characterizes a new social form of the information society. This society is a network society. The network so- 
ciety took over the hierarchical society at the beginning of the 21st century [10]. But now we are talking about the technology of global and local networks. Social networks, Twitter, Facebook, as well as related social processes have come to the fore recently. Now the influence of these new network technologies on social processes, elections, the development of democracy, the emergence of Twitter is increasing.

Communication interactions are coming to the forefront and contribute to the introduction of the concept of information and communication technologies. For some time, IT (information technology) and ICT (information communication technology) have been regarded considered similarly. The digitization of information contributes to the emergence of the digital technology concept. The digital world [18, p.53-57] is becoming a worldview. Today, digital technologies characterize the modern development of information and communication technologies. In recent years, international conferences on digital technologies have been actively held. The emergence of digital technology expands the technical and technological basis of the information society. There doesn't exist any other base except a digital one. Telecommunication systems exist on a digital basis. The concept of information and communication technology is increasingly used in intersubjective and subject-to-subject interactions. Information and communication technologies emerge pedagogical and educational technologies, as well as political technologies. There is a need to understand the special social content of information that is broadcast, transmitted, created and reproduced in these technologies. There appears the concept of social information technology.

The study of the interaction of human consciousness and thinking and information processes expands the range of information technologies. Technologies of various types of realities appear - virtual, cognitive, augmented. The technology of virtual reality is revealed as a technology of generating reality in which training can be carried out. Virtual reality is also revealed as a new technology that combines the consciousness and actions of many people into a single whole. Virtualistics discovers new dimensions of virtual reality. This is primarily the process of visual information transmission through computer screens. This is also the emergence of a new virtual being of information, through which social connections are realized in the global network.

Introduced by A. Turing, combinatorial approach and calculation of combinations [30] can be considered as a prerequisite for the introduction of a computational approach and computer metaphor in cognitivism. Computer metaphor (Newell, Simon) [17] reproduces the unity of the operations of human thinking and the computer. The treatment of signs and symbols is displayed in the foreground. The "Chinese Room" [22, p.115-116] experiment shows that not only the person, but also the computer, which has no consciousness and understanding, performs actions on signs and symbols. Communication of the processing of signs and symbols with the execution of certain operations becomes important for programming. Symbolic information processing is brought to the fore. The hypothesis of the physical existence of symbols [14, p.804] becomes an important component of the substantiation of the objectivity of the existence of information processing processes. The application of these ideas contributed to the development of artificial intelligence.

The development of programming contributed to the emergence of complex software and hardware systems. Symbolic processing of information received its continuation in the development of programming languages. The introduction of complex software and hardware systems creates prerequisites for the development of information processing at multiple levels. Programs leap from the level of machine control to the levels of the architecture of software systems.

The development of information processing technology in the early nineties leads to the emergence of complex discrete technical systems, for which the struggle with complexity becomes important. Prerequisites to shift the sphere of software system designing to a qualitatively new level are arising. This is the level 
of the research domain (G. Booch) [4, p.162]. It also creates the prerequisites to create software systems where the subject area is associated with social functionality [21, p. 84]. Multilevel information processing here is complemented by the introduction of software systems in various spheres of public life, as well as in business [21, p.85].

Technical and technological development of information technologies as technologies for creating, storing and processing information becomes decisive in the development of the information society and the main objective criterion and indicator of this development.

The development of cybernetic approach introduces the idea of control in systems of varying degrees of complexity. The cybernetic approach considers a feedback system.

The functionality revolution that took place in the second half of the nineties in the countries where the technical and technological development of information technology was brought to the fore, has contributed to the spread of information technology in all the spheres of public life.

The emergence of virtual and cognitive reality is one of the hallmarks of the nineties. The concept of cognitive reality technology was proposed by A. Zenkin [31, p.72-75]. Cognitive reality technology creates a new integrity, including the actions of man, his mind and human interaction with the computer. Technologies of augmented reality, which arise later, characterize the possibilities of including expert knowledge and various types of information (including graphic) directly into the process of human perceptual information processing. In conditions of extreme activity (military actions, rescue operations, etc.) such augmented information processing becomes crucial.

The emergence of manipulative and other technologies influencing human consciousness in the information space actualizes the issue of information security. Information technologies provide the possibility of obtaining objective information at all levels - from an individual to the society and state. The distribution of bots, fakes and bogus information stimulates the development of information technology to identify false and incomplete information.

Recent spread of cyberattacks and unauthorized interference in the process of information exchange necessitates the development of cyber security technologies. Cyber security technologies are aimed at protecting critical cyber structures. Critical cyber structure characterizes the growing importance of technologies that regulate and determine the quality of the information component of financial institutions, banks, law enforcement and government agencies and other systems.

The development of democracy in the modern global network world involves the use of Facebook, Twitter and other social networks as democratic institutions. The exchange of information in the process of communication acquires the value of the development of social emotions. This becomes the mechanism of communication of power and society. At the same time, this determines the independence of information processes from the government, which characterizes the ability of society to form its viewpoint. The development of egovernment is becoming important.

The development of information technologies as communication technologies contributes to the emergence of new social institutional entities. These include the information sphere and information space. The information sphere becomes the sphere of information activity, which requires new information technologies, the institutionalization of information exchange, contributes to the development of information law. The information space brings the level of information processing to a qualitatively new level. This is the space where information products are created and function. Information product targeting to social processes is due to the impact on people's minds. There exists a complex multilevel influence on a person at verbal, emotional, psychological, conscious and unconscious levels.

The information space becomes a platform to form a democratic discourse. By drawing people of different convictions into its circle, the information space becomes a representative of public opinion and a tool for its for- 
mation. Now digital technologies create a single basis for the development of modern society. The difference in technological basis, which has been stored for many years thanks to the preservation of analogue technologies in the field of television, has disappeared. However, even a single technological base of development does not yet create a basis for overcoming the difference between the technical and technological direction in the development of the information society and the direction that is associated with the development of civilization.

The attempt of the theory of post-industrial society to establish technological determinism as the basis of social development has not been realized. Technology itself does not produce social phenomena. But one cannot deny the influence of information technology and the development of information technology on the information society development. The society would never have experienced the structural and qualitative changes that we have witnessed for the past 30 years without the development of technical and technological direction of information technology. It is impossible to consider the state of the society and the functioning processes of all its social institutions disregarding the development of information technologies.

The emergence and approval of the information sphere, information space, critical cyber structure, national information infrastructure, e-government are also impossible without taking into account information technologies. Therefore, the desire to reduce the information society in hyper reality or media space today, in the context of globalization development, reasonably pulls the country back. This is a return to outdated technical and technological forms. It is also a substitution of the progressive development in all spheres of public life on the basis of advanced technologies for creating false reality and developing manipulative technologies that assert the political discourse.

Objectively, this contradicts the public strategy to develop the information society and knowledge society as the basis for the country's progressive development and democracy.
However, overriding the digital divide and spreading digital technologies result in a country's growing competitiveness. Often digital technologies are restricted by things, personal communication, network communication. An objective indicator of competitiveness is then the development of information technologies in the field of economics and education, social and public administration, defense and health.

The study of information technology concept transformation allows to track the development of information technologies as intellectual technologies, technologies related to the development of computer engineering, communication technologies, network technologies, information technologies and information communication technologies, digital technologies, etc. The emergence of new technologies results in the new social infrastructures of the information society. There exists a transformation of the social ontology of the information society as a result of the information technology development.

At the beginning of the XX century the case touched on changing the basis of the information society, i.e. from certain information technologies to collect, log, accumulate and process information to the qualitatively new basis of the information society - software systems of the organization level. These systems are capable to perform all production as well as social function. Today we need to talk about the transformation of the social ontology in the information society, strengthening its technical and technological basis in all spheres of public life.

To emphasize the importance of the technical and technological direction of information technology development is extremely important for the future of Ukraine. In presentday concepts of the digital world and digital philosophy, only the fact of digital technology spread is emphasized. In this case, the focus shifts to processing and storage of personal information shared in social contexts. In the context of modern globalization, such concept contributes to the development of trade. However, it can not be the basis for the development of the country. 
Objective transformations of information technologies reveal changes in their content and expansion of their sphere of influence. The improvement of information technologies shows their growing influence on the development of the information society. Information technologies are included in social dimensions, transforming the essence of labor, ways of implementing intellectual activity, performing production and social functions. The study of the influence of information technologies on social processes and phenomena opens up the horizons of the future world order.

Information technology can be classified according to the sphere of its application. Information and communication technologies characterize subject-to-subject interactions, among which pedagogical and political technologies are primarily distinguished. A separate area of information application technology is the information space. Information processing technologies in the information space are the basis of modern democratic discourse. An important constituent of information technology is the information sphere. This is the information sphere of information activity, information exchange and information relations, the regulator of which is the information law. Information security technologies ensure the protection of human rights, society and the state in obtaining objective information. Cybersecurity technologies protect critical infrastructure. The technologies of reality - virtual, cognitive, and augmented - provide the ability of a person's consciousness

\section{REFERENCE}

1. Bell D., 1996. The Coming of the PostIndustrial Society. New York, 618.

2. Bell D., 1999. The Coming of Post-Industrial Society. New York: Basic Books.

3. Bodriyyar J., 1997. Xerox and Infinity. Moskva, Prozrachnoct zla, Dobrosvet, 80-87 (in Russian).

4. Booch G., 2008. Object-Oriented Analysis and Design with Applications. 3nd ed. In Russian translated from english. Moscow, Izd. Dom Viliams, St.-Peterburg, Kyiv, 720.

5. Burdick A., Drucker J., Lunenfeld P., Presner T., Schnapp J., 2012. Digital Humanities. Cambridge, 176.
6. Castells M., 2010. The Rise of the Network Society. Second edition. With a new preface. WILEY A John Wiley \& Sons, Ltd., Publication BLACKWELL, 597.

7. Castells M., 2004. Information Technologies, Globalization and Social Development. Kyiv, Ekonomika znan: vукlуку globalizacii i Ukraina, 83-87 (in Ukrainian).

8. Dyatlov, S.A. 2000. Principles of the Information Society. Informatsionnoe Obshhestvo, No.77-85 (in Russian).

9. Debord G., 1967. The Society of the Spectacle. New York, 160.

10. Huntington Samuel P. 2005. Who Are We?: The Challenges to America's National Identity. Simon \& Schuster, 448.

11.Hodges Andrew, 1983. Alan Turing: The Enigma. New York, Simon end Shuster, 608.

12.Maksimov V.I., Kornoushenko E.K., Kachaev S.V., 1999. Cognitive technologies to support management decision making. Moscow, Informacionnoe obshhestvo, No.2, 50-57 (in Russian).

13.Li Endryu, 2016. Information - Overcoming Uncertainty. M., Sb.: Teorii vsego na svete. Pod red. Dzhona Brokmana, «Binom»; Laboratoriya znaniy, 162-163 (in Russian).

14.Luger J.F., 2003. Artificial Intelligence: Strategies and Methods for Solving Complex Problems. 4nd ed. In Russian translated from english. Moscow, Vil'yams, 864.

15.Masuda Y., 1981. The Information Society as Post-Industrial Society. Wash, 141.

16.McLuhan Marshall, 1964. Understanding media: the extensions of man. New York, McGraw-Hill, 359.

17.Newell A., Simon H. A., 1972. Human problem solving. New York, Englewood Cliffs, Prentice-Hall, 154.

18.Okinawan Charter for a Global Information Society, 2000. Moscow, Informacionnoe obshestvo, No. 4, 53-57 (in Russian).

19.Preston D., 2014. Some Ontology of Interactive Art. Philosophe and Technology, Vol.27, No.2, 267-278.

20.Robertson D.S., 1990. The information revolution. New York, Communications Press, Vol.17, No. 2, 235-254.

21.Rubanets O.M., 2006. Information society: cognitive creativity of post-classical research. Monografia. Kyiv, Vyd. PARAPAN, 420 (in Ukrainian).

22. Searle, J. 2001. Chinese Room Argument. The MIT Encyclopedia of the Cognitive Sciences. A Bradford Book, New Edition, 1096. 
23.Simons A.J.H., 1995. A Language with Class: The Theory of Classification Exemplified in an Object-Oriented Programming Language. http: Sheffield, PhD Thesis, Department of Computer Science, University of Sheffield, 255.

24.Simons A.J.H., 2002. The Theory of Classification. Journal of Object Technology. MayJune, 55-61.

25.Shadrin A.E., 2002. Information Technologies: Contribution to Social Capital. Moscow, Informatsionnoe Obschestvo, No.01, 8-12 (in Russian).

26.Shevchuk O.B., Golobutsky O.P., 2001. EUkraine. Information society: to be or not to be. Kyiv, ZAT ATLANT-UMS, 104 (in Ukrainian).

27.Sukach M., 2015. First international scientifically-practical conference Underwater technologies, 2015. Kyiv, Underwater Technologies, Vol.01, 3-12 (in Ukrainian).

28.Tapscott D., 1999. Electronic-digital society. In Russian translated from English. Kyiv, INTpress, Izd-vo, Moscow, Refl-buk, 432.

29. Toffler A., 1990. The Third Wave. New York, Bantam Books, 537.

30.Turing A.M., 1950. Computing Machinery and Intelligence. Source: Mind, New Series, Vol.59, No.236 (Oct.), 433-460.

31.Zenkin A.A., 1996. Knowledge-generating technologies of cognitive reality. Moscow, Novosti Iskustvennogo Intellekta, No.2, 72-78 (in Russian).

\section{Трансформация концепта "информационные технологии" в современном научном дискурсе}

\section{Александра Рубанеи}

Аннотация. Целью исследования является раскрытие объективных трансформаций, произошедших в информационных технологиях. Важна также концептуализация этих трансформаций. Системный, информационный, сетевой и когнитивный подходы позволяют раскрыть основные аспекты развития информационных технологий - технико-технологический, сетевой, коммуникационный, когнитивный. В статье выявлены основные этапы эволюции информационных технологий. Проанализирована связь информационных технологий с возрастанием роли и значения информации в жизни человека и общества. Информационные технологии раскрываются как технологии создания, хранения, фиксации и обработки информации.
Проанализировано технико-технологическое направление развития информационных технологий. Выявлена связь трансформации концепта информационная технология с развитием теории информационного общества, в частности теории постиндустриального общества, информационного общества, сетевого общества, общества знания и цифрового мира. Выявлена связь трансформации концепта информационная технология со становлением медиацивилизации и глобального информационного пространства. В статье показано, что развитие информационных технологий является важным фактором развития информационного общества. Переход от технологии в виде техники (электронно-вычислительная машина как машина) к современному этапу развития цифровых технологий характеризует формирование единой технико-технологической основы формирования информационного общества.

Информационные технологии делятся по сфере действия. Информационнокоммуникационные технологии характеризуют субъект-субъектные взаимодействия, среди которых прежде всего выделяются педагогические и политические технологии. Отдельной сферой действия информационных технологий является информационное пространство. Технологии обработки информации в информационном пространстве являются основой современного демократического дискурса. Важной сферой действия информационных технологий является информационная сфера. Это информационная сфера информационной деятельности, информационного обмена и информационных отношений, регулятором которых является информационное право.

Технологии информационной безопасности обеспечивают защиту прав человека, общества и государства в получении объективной информации. Технологии кибербезопасности обеспечивают защиту критической инфраструктуры. Технологии реальности - виртуальной, когнитивной, расширенной и дополненной - обеспечивают возможность сознания и мышления человека обрабатывать и создавать новую информацию. Выявление общественного значения технико-технологического направления развития информационных технологий становится основой рекомендаций для реализации общественной стратегии построения информационного общества в Украине.

Ключевые слова. Информационные технологии, информационно-коммуникационные технологии, сетевые технологии, цифровые технологии. 